\title{
INTRODUCING EDUCATION BASED ON HUMAN RIGHTS IN HIGHER EDUCATION: EXAMPLES FROM A LANGUAGE SUBJECT
}

\author{
María Martínez Lirola \\ University of Alicante, Spain and Research Fellow, Department of Linguistics and Modern \\ Languages, University of South Africa (UNISA) \\ maria.lirola@ua.es
}

First draft received: 24 July 2016

Final proof received: 20 February 2017

\begin{tabular}{l} 
Abstract \\
Despite the progress that has been carried out in different areas of society in recent years, human rights \\
are still violated in various ways in different parts of the world. This article chooses an educational \\
proposal based on human rights in order to assert their importance through various practical activities \\
carried out in higher education, particularly in a compulsory subject of the degree in English Studies in a \\
Spanish University. The purpose of the chosen activities is that students reflect on human rights so that \\
they can improve their critical awareness and their commitment in defending them. This educational \\
proposal combines the development of the different skills requested in a language subject (listening, \\
speaking, reading, writing and interaction), the acquisition of values and the importance of human rights. \\
The proposed activities contribute to students' progress as active, critical, ethical and committed \\
citizens, who are able to become aware of the different ways in which human rights are violated. \\
Moreover, they are able to provide coherent responses based on the approach that has been followed \\
in the teaching-learning process. Therefore, it is concluded that the educational approach presented in \\
this article is suitable for students to be sensitized, to develop social awareness, and to acquire different \\
skills. \\
Keywords: human rights; language teaching; didactics; higher education; English studies. \\
To cite this paper (in APA style): \\
Lirola, M. M. (2017). Introducing education based on human rights in higher education: Examples from a \\
language subject. Indonesian Journal of Education, $9(2), 82-88$. doi: dx.doi.org/10.17509/ije.v9i2.5461 \\
\hline \hline
\end{tabular}

\section{INTRODUCTION}

The twenty first century society highlights globalization and the fact of being in contact with other people through social networks. Consequently, cultural approaches take place, and it is also possible to be aware of unfair social situations that take place in different parts of the world, although there are many advances taking place in social life. This article presents some activities framed on Education Based on Human Rights (EBHR) because this pedagogical perspective places the human being in the centre of its interventions and help people be aware of the importance of human rights (HHRR); in this sense, each human is considered the protagonist of her/his personal and social development, at the same time that she/he is the holder, owner and promoter of her/his rights (Agencia de Naciones Unidas para los refugiados de Palestina, 2014, p. 8).

Human rights are normally defined as those rights that are inherent in our nature; we cannot live as human beings without them (Naciones Unidas, 2004). The Universal Declaration of Human Rights takes into account ideals of coexistence that make it be considered one of the best works of the history of humanity (Mestre Chust, 2007). It is necessary to keep in mind that human rights are not respected in many places; therefore, it is important to continue working to make them visible and a reality for many human beings.

In fact, EBHR contributes to improve communication in a foreign language classroom if students develop the different skills (listening, speaking, reading, writing and interaction) in order to improve their level of English, following Lopes Cristovão (2015, p. 411): "First, the starting point of a didactic intervention should be based on a communicative situation with a clear objective to be achieved and a purposeful prompt for text production". Therefore, this educational proposal combines that students develop the said skills with teaching the importance of human rights and of education based on values.

In addition, this perspective contributes so that students advance as global citizens in such a way that they can be aware of the different social realities that take place at local and global levels, and they assume a commitment in order to improve society. We believe that every learning experience has its origin in a social environment (Antón, 2010). Consequently, it is important to maximize that students are active, critical and committed in the teaching-learning process (Barahona et al., 2013); they are educated to be global citizens. Moreover, this pedagogical proposal promotes values and the importance of peace for a better society, following Page (2008, p. 3):

The Universal Declaration of Human Rights recognizes peace education in Article 26: "Education shall be directed [...] to the strengthening of respect for human rights and fundamental freedoms. It shall promote understanding, tolerance and friendship [...] and shall further the activities of the United Nations for the maintenance of peace. 
Education for global citizenship implies that students acquire competences and values that favour the exercise of HHRR, which implies responsibility in the construction of a better world and active participation both inside and outside the classroom (United Nations, 2006). The pedagogy based on human rights is not normally a priority in higher education. This is not surprising since HHRR are a topic that is not quite visible among the main discourses, such as the one highlighted by the media.

In this sense, it is important to highlight that the classroom is a space where we can observe how society works, following Fernández Martínez (2011, p. ix): "The classroom offers tangible ways of interpreting contemporary culture; it is an excellent forum for teaching discourse analysis and for making students aware that there is a complex world there to be analysed."

The classroom can be used as a space where human rights are visible, although it is not very frequently that they are present (Goodhart and Mihr, 2011; Porter and Offord, 2006). For this reason, their claim is essential so that societies advance with justice, equality in rights, peace, among others (Goh et al., 2012), in words of Gready and Vanhenhole (2014, p. 12):

\begin{abstract}
A human rights framing is attractive to social justice advocates because it speaks of entitlement, not charity; provides a language in which transnational discussions can take place; and brings to bear an international legal framework with claims to universal acceptance that outstrip other normative frameworks.
\end{abstract}

The main objective of this article is to offer some activities framed on EBHR in a Spanish language classroom in order to make visible the said pedagogical perspective in higher education. Another objective of this article is that students reflect on human rights in order to improve their critical awareness and their commitment in their defence. EBHR offers students opportunities to reflect and deepen in the different ways in which HHRR are violated. It also proposes that students are more ethical and critical in order to be able to contribute to look after human rights. After this introduction, this article is organised in the following way: the next section offers the literature review and the main principles of EBHR. Next, section 3 refers to the context of the research, the participants and the methodology that was used. Section 4 offers some practical examples of activities used in the language classroom related to human rights. Section 5 consists on the discussion and finally, the paper finishes with some conclusions.

\section{LITERATURE REVIEW}

The EBHR gives importance to the Universal Declaration of Human Rights because one of its main concerns is that the said rights are known and respected; this framework also pays attention to social problems such as war, gender discrimination, and environmental problems, among others. Consequently, EBHR considers essential freedom of thought and expression so that students can be active participants in the teaching-learning process and can advance as active citizenship (Al-Nakib, 2012; Covell, 2013; Tibbits, 2005).

The Universal Declaration of Human Rights, which was signed after the atrocities of the Second World War, recognizes that human rights are the base for freedom, justice and peace. These imply that they are inherent to the dignity of all human beings irrespective of their race, sex, religion, social class, place of residence, ideology, etc. HHRR are expressed as civil, social, and economic rights, and it is necessary to ensure that they are accomplished and respected through the various laws that governments prepare for this purpose. Human rights are a set of guarantees and freedoms that States must respect and enforce, and that all people have because of being human (Barbeito and Caireta, 2009). These authors (2009, p. 11) indicated that human rights have three key features: a) universal: they are valid for all people of the world, without any exception; b) inalienable: they cannot be denied, suspended, or withdrawn; and c) indivisible: they cannot be separated or ranked and they are all related and have the same value.

The fact that these rights are universal highlights their value in the fight for equality and nondiscrimination. In fact, this approach gives a special attention to the most marginalized and vulnerable groups in society; it also highlights the active participation of all persons in the respect of HHRR and in building a more just, equitable and democratic society. As Osler and Starkey (2010, p. 43) make clear:

The Universal Declaration of Human Rights (UDHR) presents a vision of a peaceful world; the outcome of a struggle by humanity to implement justice. It offers an emancipatory manifesto, a set of shared principles for living together and an agenda for action developed in response to the repressive totalitarian ideologies of the midtwentieth century. The realisation of this vision of justice and peace is a utopian project.

Opting for a human rights approach allows to establish an interdisciplinary connection based on contents that takes into consideration social problems that are present in near and far environments. Consequently, students develop a critical vision that enables them to be aware of how Human Rights are not respected; this awareness must imply that students commit in their defense in order to make real their progress as responsible, active, and engaged citizens.

Magendzo (2015, p. 48) pointed out that EBHR began with social and popular education movements. Following the United Nations Fund for Children (2008), this model is based on the idea that education officially enjoys the status of human right since the Universal Declaration of Human Rights was adopted in 1948. Therefore, this approach can be considered transformer because it is aimed at creating an active society in which each person is empowered and able to demand respect for their rights (Acebal Monfort et al., 2011; Magendzo and Donoso, 1999).

There is research that focuses on human rights in general or regarding HHRR from a sociological or political perspective (Holder and Reidy, 2013; Kadragiz, 2006; Marchetti \& Tocci, 2011; Risse et al., 
2013; Steiner et al., 2007). Other studies join HHRR with migration (Blake and Husain, 2003; Dembour and Kelly, 2011; Estévez, 2012; Rubio-Marín, 2014). There are also publications linking human rights to education, which is an area of special interest for this paper (Bajaj, 2003, 2011; Caicedo, 2014; Covell, 2013; Osler and Starkey, 2010; Pani et al., 2005; Simon and Pleschová, 2013; Tomasevski, 2006). In this sense, it is understood that EBDH highlights that students are active in the educational process and society so that students' capacities get stronger and they become active in social relations (Caicedo, 2014).

Taking into account the indications of the United Nations (2004), education based on human rights shares giving a core value to the principles present in the declaration of rights such as equality and dignity; it is accepted the universality, indivisibility and interdependence of human rights. This educational framework is based on documents such as the Universal Declaration of Human Rights or the Convention on the Rights of the Child; it also establishes relationships between human rights and individual responsibilities of the State. In addition, HHRR are understood as an evolving process to help understand human needs and the role of citizens and the State in their respect.

Education must be understood as an element that contributes to the development of the human being and to the development of society. In fact, education must contribute to promote fundamental freedoms and respect for human rights. This educational approach is also a tool for social transformation that involves empowering people by giving children and adults the opportunity of being aware of the importance of their rights (Pani et al., 2005).

Human rights can be considered a common ground between different trends in education such as development education, conflict resolution, peace education, multicultural education or global education. I concur with the statement of Tibbits (2008, p. 99): "Human rights education is an international movement to promote awareness about the rights accorded by the Universal Declaration of Human Rights (UDHR) and related human rights conventions, and the procedures that exist for the redress of violations of these rights". Thus, education based on human rights can teach many skills that help students to defend human rights such as to be open to other cultures, to appreciate the value of freedom, to respect differences and dignity, to contribute to the prevention of conflicts and to resolve them by non-violent means, among other issues.

\section{METHODS}

The context of this article is higher education, i.e., the activities that presented in the following section were put into practice in the core subject English Language $\mathrm{V}$ in the degree English Studies (Grado en Estudios Ingleses) at the a university in Spain. The end of this subject is that students acquire an advanced level of English by developing the different skills. The subject is taught 4 hours a week and each hour is devoted to work with different skills: academic writing (the main cohesive devices and the main formal and functional aspects of the main text types are explored); revision of the main grammatical aspects that level $\mathrm{C} 1$ requests (inversion, passive voice, reported speech, etc.); oral skills are paid special attention and that is why one hour is used every week for students to present a cooperative oral presentation and another hour is used in the participation in a debate on the same topic that the oral presentation so that students can develop their critical thinking and talk about global issues.

The participants of this research were the 125 students registered in the subject English Language $\mathrm{V}$ during the academic year 2014-2015. The majority were women $(85 \%)$ and $15 \%$ were men. Most of the students were 21 years old and they have studied English as a compulsory subject in the first and second year of the degree, which means that they got level B1 in the first year and level B2 in the second year. Most of the students wanted to work as primary or secondary school English teachers, but there were also students who wanted to work as translators or interpreters in Spain or abroad.

As regards methodology, due to the high number of students registered in the subject, the teacher, who is also the person is charge or doing this study, i.e., this is practitioner research, decided to use a cooperative methodology in order to be in contact with group coordinators in order to supervise students' learning process easier. Students were asked at the beginning of the academic year to organise themselves in groups of 5 or 6 people; they could work cooperatively during the whole semester in the different activities they were asked to do.

Due to the limitations of space in this paper, I am just going to offer a detailed description of some of the activities that students had to do during the semester framed in the pedagogical proposal of EBHR (see section 4). They have been chosen for their appropriateness to develop social awareness at the same time that they work with the five skills.

The choice of this type of methodology entails that students are the protagonists in the teachinglearning process, while the teacher assumes a role of facilitator or guide. The fact that the methodology is cooperative promotes interaction as the basis for developing the proposed activities effectively. In essence, the acquisition of different types of skills takes place. Therefore, the methodology proposed contribute to establish a relationship between what is taught in classrooms and the demands of society because students develop critical thinking, work in groups, integrate different skills, broaden their perspective, etc.

\section{FINDINGS}

\section{Cooperative activities that promote human rights}

In order to implement a framework based on human rights, necessary the use of appropriate materials is necessary, i.e., materials must inform and raise awareness, facilitate dialogue and debate so that students can express freely; in addition, materials should be helpful and facilitate students to be able to offer positive responses to meet global challenges. It is not usual that textbooks have sections devoted exclusively to human rights. In this sense, it is desirable that teachers design their own materials using authentic texts and of course the Universal Declaration of Human Rights in order to work in a 
rights-based approach effectively, as the activities described below show.

\section{Activity 1: Working on racial diversity}

The teacher selects different multimodal texts of advertising in which people of different races are represented in order to help students think about the situation and the social reality of people living in other continents and whose cultures are different from the students. Students have to write down the main cultural differences observed between the people that appear on the texts and their own culture. In this way students deepen into the construction of identity and different cultures (Coates, 2012; Martínez Lirola, 2013; Ortiz et al., 2005), following Brooks and Hebert (2006, p. 297):

\begin{abstract}
Much of what audiences know and care about is based on the images, symbols, and narratives in radio, television, film, music, and other media. How individuals construct their social identities, how they come to understand what it means to be male, female, black, white, Asian, Latino, Native American- even rural or urban-is shaped by commodified texts produced by media for audiences that are increasingly segmented by the social constructions of race and gender. Media, in short, are central to what ultimately come to represent our social realities.
\end{abstract}

Once students have written the ideas, they share what they thought after seeing the texts. Next, the class is divided into five groups and each group is assigned a continent. The different people who make up the groups have to think of five advantages and five disadvantages of belonging to the continent that has been assigned and think of possible solutions to improve the disadvantages. Then, each group shares its list and the teacher writes down the ideas on the blackboard. After that the groups have to choose one nationality within the continent allotted and think about different stereotypes associated with nationality.

After that, a person of another group comes at the center of the class and he/she puts a sticker on the forehead with the name of the nationality by another group; the person at the center does not know what nationality it is written on the sticker. Once this is done, people from different groups begin to say stereotypes or positive aspects that are related with that nationality until the person at the center guess which one it is. At the end of the session, the teacher encourages a debate that discussed what of these stereotypes may be true and if people tend to learn more stereotypes or the positive aspects of certain nationalities.

\section{Activity 2: Deepening into Human Rights}

After the preparatory activity where some stereotypes have been made visible, the purpose of the next one is to deepen on human rights in order to emphasize their importance in today's society and to deepen on how they relate to intercultural competence. The teacher asks students how many human rights they know; they are asked to appoint at least one, and students need to share if they think that to talk about human rights is a current topic. All these questions are answered in groups and then a spokesperson is appointed in order to synthesize all the ideas discussed in groups in front of the whole class. After answering these questions the teacher refers to some human rights, such as the following, and asks students if, in their opinion, these rights are respected or further work is needed to be done so that they are respected:

Article 1:

All human beings are born free and equal in dignity and rights. They are endowed with reason and conscience and should act towards one another in a spirit of brotherhood.

\section{Article 2:}

1. Everyone is entitled to all the rights and freedoms set forth in this Declaration, without distinction of any kind, such as race, colour, sex, language, religion, political or other opinion, national or social origin, property, birth or other status.

2. Furthermore, no distinction shall be made on the basis of the political, jurisdictional or international status of the country or territory to which a person belongs, whether it be independent, trust, non-self-governing or under any other limitation of sovereignty.

Article 4:

No one shall be held in slavery or servitude; slavery and the slave trade shall be prohibited in all their forms.

\section{Article 5:}

No one shall be subjected to torture or to cruel, inhuman or degrading treatment or punishment.

\section{Article 28:}

Everyone is entitled to a social and international order in which the rights and freedoms set forth in this Declaration can be fully realized.

Then, the teacher asks the students in what continent/s there are more violations of human rights and the reasons they can think of for these violations to take place. In fact, students have to discuss how these rights are not respected (rights denied by gender, race, religion, sexual orientation, etc.), talk about countries where human rights have improved recently, etc.

Students are also asked to think of organizations that work for the defense of human rights and of human rights activists and defenders of peace; they also have to reflect on what human rights violations are the ones that bother them most and the reasons for that. In addition, students have to prepare a list of vocabulary known and unknown related to human rights; in this way, they expand their vocabulary related to this semantic field; they are also asked to prepare a glossary related to this issue.

We consider that it is important that students link the global reality with the local one; in this sense, after this first part of the activity that is more general, students are invited to reflect on how it is necessary to improve human rights in their local reality. The teacher asked the following questions to the groups and calls for a different person to be the leader of the group and write down the main ideas discussed in 
groups. Afterwards, these ideas can be shared with the rest of the class:

- Do you know situations in your local reality in which human rights are violated by not accepting cultural differences?

- What happens in your context when a violation of human rights takes place?

- Are there places in this community where people can participate actively in the protection of human rights violations or prevent them up to a certain extend?

After conducting the discussion, the teacher distributes magazines, newspapers, markers, glue and scissors for students to prepare in various groups different murals related to the importance of multiculturalism and the respect of human rights so that society can advance. The murals are used to decorate the classroom. In this way, multimodal materials made by the students themselves are employed, giving space for creativity in the higher education classroom.

\section{DISCUSSION}

The activities outlined in the previous section aim that students deepen on human rights, learn more about them, and are able to think of situations where they are violated and of actions that could be taken to defend and respect them. Moreover, students learn vocabulary and conversational skills based on practical activities that promote human rights. In this way, the language classroom takes into consideration teaching values at the same time that students work with the different skills that they have to develop in the foreign language, i.e., listening, speaking, reading, writing and interaction. We are, therefore, in front of an educational proposal that helps to break with prejudices and stereotypes and to emphasize the defense of human rights and peace. Consequently, it highlights the development of attitudes that help promote respect and tolerance for diversity at the same time that students are aware of the individual and collective rights.

One of the purposes of EBDH in the subject English Language $\mathrm{V}$ is to make students recognize the importance that human rights have in their lives, in their families' lives and in society; another purpose is to make students aware of how the respect for HHRR varies in different parts of the world. Human rights are not something to be learned by heart but their teaching should be done through practical activities that are contextualized as those presented in this article. In this sense, our educational proposal provides opportunities for students to reflect on how human rights are violated so that they can provide solutions to ensure them. They are offered controversial situations so they have to develop critical thinking and to reflect and offer solutions integrating different competences (Magendzo, 2015).

After the ideas presented in the preceding paragraph, it is clear that opting for EBDH offers students opportunities to reflect on the various problems that society has at the present time and promotes working with the principles of critical pedagogy (Magendzo and Toledo, 2015). HHRR should be taught in all the subjects in the curriculum or through concrete activities such as those presented in this article.

Therefore, this approach is committed to enhance participatory knowledge in the teachinglearning process, which involves that students learn in a dynamic way and based on dialogue leading to respect different opinions and deep reflection in which the rights of others are recognized (Bárcena and Melich, 2000). This entails the development of critical thinking, which is essential for the students to recognize that they are active and critical citizens in the twenty-first century and in building a better world for all people who inhabit it. In addition, it is highlighted that students have a global vision of the world, which should start from their daily reality and have as axis on human rights.

The fact that the first activity pays special attention to racial diversity linked to human rights carries with it an invitation for students to respect cultural diversity and see it as an opportunity for cultural enrichment. This involves making progress in building an increasingly democratic society in which the peaceful coexistence of all people regardless of their race, sex or any other difference is encouraged. This activity aims to end the ethnocentrism that is present on many occasions when people have not gone deep enough or do not know other cultural or racial realities.

The second activity encourages students to work with the Declaration of Human Rights and respond to the specific questions raised in order to have more knowledge about HHRR and to have more tools and arguments to defend and argue about the importance of these rights so that societies can advance in rights and in respect for differences. Activities one and two are intended to make students reflect about the close relationship between not respecting differences among people, especially the cultural ones and the violation of human rights. It is emphasized that racial segregation often carries rejection not only of the color of the skin but also of different cultural aspects related to certain races, countries or continents.

Knowing human rights helps the students to have a globalist vision of reality and to be more open to realities different from their own. The fact of designing activities that deepen in the defense of human rights highlights that the subject is not only focused on learning the foreign language but it shows that English Language $V$ is also designed to help students be committed to a broader approach that makes them aware of HHRR and of different social realities. In fact, this teaching proposal tries to make connections between what is taught in the classroom and what happens in society. In this sense, students can see that they improve their English at the same time that they acquire more social consciousness.

When doing the activities presented in the previous section, students improve in various skills because all the activities take into account that they are framed in a foreign language classroom, which involves the development of written and spoken communication. The activities are designed to help students improve their English while working on a rights-based approach that involves the awareness of social problems and the acquisition of social skills such as active listening, respect for diversity of opinions, communication, among others. Therefore, 
this pedagogical approach highlights social awareness and openness to know other social realities and how human rights are not respected or not in different parts of world.

Students develop their skills at the same time that they reflect on the social issue under study in different ways: reading the Declaration of Human Rights, writing about what they are asked taking into account $\mathrm{EBDH}$, talking with their classmates, listening to different opinions and sharing in front of the whole class, among others.

\section{CONCLUSIONS}

Basing education on human rights is fundamental to build fair and egalitarian societies. However, in general, we lack educational proposals based on EBDH in higher education. Hence, the learning model presented in this paper is a proposal to enhance that students learn not only English but also acquire competences to discuss on the importance of human rights; students are invited to broaden their perspective and to realize that one can learn English while deepening on critical thinking. Moreover, it is highlighted the importance of ensuring respect for human rights while learning English.

EBHR emphasizes that all human beings have the same dignity and that relationships must be based on respect for diversity, justice and equality, among others. Consequently, all forms of discrimination and violence are rejected in order to advance in the development of a peaceful, egalitarian, and respectful society that respects diversity. Furthermore, this approach enables students to protect and respect rights by being aware of their importance. This educational approach helps build a global ethic where an explicit commitment to peaceful conflict resolution and fair negotiation is present. In addition, this approach contributes to the development of democratic capacities and to promote the comprehensive development of students by promoting critical reflection that helps them go beyond content acquisition.

EBHR is an educational proposal that gives great importance to the fact that students learn by doing, i.e., they work with different skills during the whole teaching-learning process, which is a key idea in an active learning model as the one proposed. Framing pedagogy on an approach based on human rights enhances global awareness. In addition, it contributes to building a better world if students actively engage and capture the essence of each of the activities.

It is necessary to put into practice more educational proposals based on human rights in order to help students of all educational levels to be enriched with what this approach offers. In a sense, they can become aware of the importance of human rights so that societies can advance and human beings are treated with respect and dignity. In short, the EBDH is a pedagogical and political strategy that contributes to the development of active citizenship and to the creation of a real democracy.

\section{REFERENCES}

Acebal Monfort, L. (coord.), Fernández Aller, C. \&

Romero, E. de (2011). El enfoque basado en
Derechos Humanos y las políticas de cooperación internacional Análisis comparado con especial atención al caso español. Madrid: Asociación Pro Derechos Humanos de España.

Agencia de Naciones Unidas para los refugiados de Palestina, UNRWA España. (2014). Cuaderno pedagógico. La paz empieza aquí. Educación en Derechos Humanos. Madrid: Agencia de Naciones Unidas para los refugiados de Palestina.

Al-Nakib, R. (2012). Human rights, education for democratic citizenship and international organisations: findings from a Kuwaiti UNESCO ASPnet school. Cambridge Journal of Education, 42(1), 97-112. https://doi.org/10.1080/0305764X.2011.652072.

Antón, M. (2010). Aportaciones de la teoría sociocultural al estudio de la adquisición del español como segunda lengua. RESLA, 23, 930.

Bajaj, M. (2003). Guía de educación en derechos humanos. Santo Domingo: UNESCO.

Bajaj, M. (2011). Human rights education: Ideology, location and approaches. Human Rights Quarterly, 33, 481-508. doi: 10.1353/hrq.2011.0019.

Barahona, R., J. Gratacós \& Quintana, G. (2013). Centros educativos transformadores. Ciudadanía global y transformación social. Barcelona: Oxfam Intermón.

Barbeito, C. \& Caireta, M. (2009). Juegos de paz. Caja de herramientas para educar hacia una cultura de paz. Madrid: Los libros de la Catarata.

Bárcena, F. \& Melich, J. M. (2000). La educación como acontecimiento ético: natalidad, narración y hospitalidad. Madrid: Paidos.

Blake, N. \& Husain, R. (2003). Immigration, Asylum and Human Rights. Oxford: Oxford University Press.

Brooks, Dwight E. \& Hebert, L. P. (2006). Gender, race and media representation. In B. J. Dow and J. T. Wood (Eds.). The Sage Handbook of Gender and Communication (pp. 297-317). London: Sage Publications.

Caicedo B., S. A. (2014). Derechos humanos: herramienta para resolver conflictos escolares en la discriminación de género. Via Inveniendi et ludicandi, 9(1), 74-98.

Coates, J. (2012). Gender and Discourse Analysis. In J. P. Gee and M. Handford (Eds.). The Routledge handbook of discourse analysis (pp. 90-103). London: Routledge.

Covell, K. (2013). Educación de los derechos humanos de los niños como medio para la justicia social: Un estudio de caso desde Inglaterra. Revista Internacional de Educación para la Justicia Social (RIEJS), 2(1), 35-48.

Declaración Universal de los Derechos Humanos (1948). Resolución de la Asamblea General 217 A (III), de 10 de diciembre de 1948. U.N. Doc A/810, 71 (1948).

Dembour, M. B. \& Kelly, T. (Eds.) (2011). Are human rights for migrants?: critical reflections on the status of irregular migrants in Europe and the United States. London/NewYork: Routledge.

Estévez, A. (2012). Human rights, migration, and social conflict: toward a decolonized global 
justice. New York: Palgrave Macmillan. https://doi.org/10.1057/9781137097552

Fernández Martínez, D. (2011). Introducing discourse analysis in class. Cambridge: Cambridge Scholars Publishing.

Fondo de las Naciones Unidas para la Infancia (2008) Un enfoque de la educación basado en los derechos humanos. New York: Organización de las Naciones Unidas.

Goh, B. C, B. Offord \& Garbutt, R. (Eds.). (2012). Activating human rights and peace. Theories, practices and context. Surrey/Burlington: Ashgate.

Goodhart, M. \& Mihr, A. (Eds.). (2011). Human rights in the $21^{\text {st }}$ century. Continuity and change since 9/11. New York: Palgrave Macmillan. https://doi.org/10.1057/9780230307407

Gready, P. \& Vanhenhole, W. (2014). "What are we trying to change? Theories of change in and human rights". In P. Gready and W. Vanhenhole (Eds.). Human rights and development in the new millenium. Towards a Theory of Change (pp. 1-26). London/New York: Routledge.

Holder, C. \& Reidy, D. (Eds.) (2013). Human rights. The hard questions. Cambridge: Cambridge University Press. https://doi.org/10.1017/CBO9780511758553

Kadragiz, A. (2006). Globalization and human rights. Philadelphia: Chelsea House Publishers.

Lopes Cristovão, V.L. (2015). A genre-based approach underlying didactic sequences for the teaching of languages. In N. Artemeva and A. Freeman (Eds.), Genre studies around the globe: Beyond the three traditions (pp. 403-424). USA: Trafford.

Magendzo, A. (2015). Educación en derechos humanos y educación superior: una perspectiva controversial. Reencuentro: Derechos Humanos y educación superior, 70, 47-69.

Magendzo. A. \& Donoso, P. (1999). Diseño curricular problematizador en la enseñanza de los derechos humanos. Cuadernos de Educación en y para los derechos humanos. Santiago de Chile: IIDH-PIIE.

Magendzo, A. \& Toledo, M. I. (2015). Educación en derechos humanos: Estrategia pedagógicadidáctica centrada en la controversia. Revista Electrónica Educare, 19(3), 1-16. https://doi.org/10.15359/ree.19-3.2.

Marchetti, R. \& Tocci, N. (Eds.) (2011). Civil society, conflicts and the politicization of human rights. Tokyo/New York/ Paris: United Nations University Press.

Martínez Lirola, M. (2013). Teaching visual grammar and social issues in an English language course: an example using multimodal texts on immigrant minors from a Spanish newspaper. In
F. J. Díaz Pérez, M. B., Díez-Bedmar, P. García-Ramírez and D. Rascón-Moreno (Eds.). Global issues and the teaching of language, literature and linguistics (pp. 195-215). Viena: Peter Lang.

Mestre Chust, J. V. (2007). La necesidad de la educación en derechos humanos. Barcelona: Editorial UOC.

Ortiz García, C., Sánchez Carretero, C. \& Cea Gutierrez, A. (Coords.) (2005). Maneras de mirar. Lecturas antropológicas de la fotografía. Madrid, Editorial CSIC.

Osler, A. \& Starkey, H. (2010) Teachers and human rights education. London: Trentham Books.

Page, J. S. (2008). Peace education: Exploring ethical and philosophical foundations. Charlotte: Information Age Publishing.

Pani, A., Bijayalaxmi, M. \& Rishi Dev A. (2005). Human rights education. New Delhi: Association of Indian Universities.

Porter, E. \& Offord, B. (Eds.). (2006). Activating human rights. Bern: Peter Lang.

Risse, T., Ropp, S. C. \& Sikkink, K. (2013). The persistent power of human rights: from commitment to compliance. Cambridge: Cambridge University Press. https://doi.org/10.1017/CBO9781139237161.

Rubio-Marín, R. (2014). Human rights and immigration. Oxford: Oxford University Press. https://doi.org/10.1093/acprof:oso/97801987011 70.001 .0001$.

Simon, E. \& Pleschová, G. (Eds.) (2013). Teacher development in higher education. Existing programs, program impact, and future trends. London/New York: Routledge.

Steiner, S., Alston, P. \& Goodman R. (2007). International human rights in context: law, politics, morals. Third edition. Oxford: Oxford University Press.

Tibbits, F. (2005). Transformative learning and human rights education: Taking a closer look. Intercultural Education, 16(2), 107-114. doi:10.1080/14675980500133465.

Tibbits, F. (2008) Human rights education. In M. Bajaj (Ed.). Encyclopedia of peace education (pp. 99-108). Charlotte, North Carolina: Information Age Publishing. https://doi.org/10.1080/14675980500133465.

Tomasevski, K. (2006). Human rights obligations in education: The 4-A scheme. The Netherlands: Wolf Legal Publishers.

United Nations (2004). ABC: teaching human rights: practical activities for primary and secondary school. New York: United Nations.

United Nations (2006). Plan de acción. Programa mundial para la educación en derechos humanos. New York: UNESCO. 